Article

\title{
Formation of Nanocrystalline Cobalt Oxide-Decorated Graphene for Secondary Lithium-Air Battery and Its Catalytic Performance in Concentrated Alkaline Solutions
}

\author{
Si-Han Peng ${ }^{1}$, Hsin-Chun Lu ${ }^{1,2, *}$ and Shingjiang Jessie Lue ${ }^{1,2,3, *(\mathbb{D}}$ \\ 1 Department of Chemical and Materials Engineering, Chang Gung University, Guishan District, Taoyuan 333, \\ Taiwan; D000015858@cgu.edu.tw \\ 2 Department of Orthopedic Surgery, Chang Gung Memorial Hospital, Keelung 204, Taiwan \\ 3 Department of Safety, Health and Environmental Engineering, Ming-Chi University of Technology, \\ Taishan District, New Taipei 243, Taiwan \\ * Correspondence: hsinchun@mail.cgu.edu.tw (H.-C.L.); jessie@mail.cgu.edu.tw (S.J.L.); \\ Tel.: +886-3-2118800 (ext. 5292) (H.-C.L.); +886-3-2118800 (ext. 5489) (S.J.L.); Fax: +886-3-2118700 (S.J.L.)
}

Received: 23 April 2020; Accepted: 1 June 2020; Published: 6 June 2020

\begin{abstract}
A potent cathode catalyst of octahedral cobalt oxide $\left(\mathrm{Co}_{3} \mathrm{O}_{4}\right)$ was synthesized onto graphene (GR) nanosheets via a two-step preparation method. The precursor cobalt solution reacted with GR during the initial hydrolysis step to form intermediates. A subsequent hydrothermal reaction promoted $\mathrm{Co}_{3} \mathrm{O}_{4}$ crystallinity with a crystalline size of $73 \mathrm{~nm}$, resulting in octahedral particles of 100-300 nm in size. Scanning electron microscopy, Raman spectroscopy, and X-ray diffraction analysis confirmed the successful formation of the $\mathrm{Co}_{3} \mathrm{O}_{4} / \mathrm{GR}$ composite. This catalyst composite was sprayed onto a carbon cloth to form a cathode for the hybrid electrolyte lithium-air battery (HELAB). This catalyst demonstrated improved oxygen reduction and oxygen evolution capabilities. The HELAB containing this catalyst showed a higher discharge voltage and stable charge voltage, resulting in a $34 \%$ reduction in overall over-potential compared to that without the $\mathrm{Co}_{3} \mathrm{O}_{4} / \mathrm{GR}$ composite. The use of saturated $\mathrm{LiOH}$ in $11.6 \mathrm{M} \mathrm{LiCl}$ aqueous electrolyte at the cathode further reduced the over-potential by $0.5 \mathrm{~V}$. It is proposed that the suppressed dissociation of $\mathrm{LiOH}$ expedites the charging reaction from un-dissociated $\mathrm{LiOH}$. This $\mathrm{Co}_{3} \mathrm{O}_{4} / \mathrm{GR}$ composite is a promising bi-functional catalyst, suitable as a cathode material for a HELAB operating in high relative humidity and highly alkaline environment.
\end{abstract}

Keywords: metal oxide nanocatalyst; air-breathing secondary battery; dual electrolytes; electrochemistry; alkaline electrolyte solution

\section{Introduction}

With the global focus on the development of alternative energy conversion and storage systems, sustainable energy technologies that are high efficiency, low cost, and environmentally friendly are desirable. Emerging applications such as fuel cells and metal/air batteries have stimulated intense research interests. Among metal/air batteries, the lithium (Li)/air battery possesses the highest theoretical energy density of $11,140 \mathrm{Wh} \mathrm{kg}^{-1}$ (when oxygen is directly supplied from the air [1]), and the specific energy of well-optimized $\mathrm{Li} / \mathrm{O}_{2}$ batteries (estimated $3000 \mathrm{Wh} \mathrm{kg}^{-1}$ ) greatly exceeds that of the state-of-the-art lithium ion batteries by up to 15 times [1]. However, there are certain challenges toward Li/air battery commercialization. Currently aprotic type Li/air batteries (using non-aqueous electrolytes) still have some critical challenges, such as low practical areal capacity, low round-trip 
energy efficiency, and strict inlet air humidity and impurity limits [2]. The aprotic Li/air battery produces insoluble discharge products (including $\mathrm{Li}_{2} \mathrm{O}_{2}, \mathrm{LiOH}$, and $\mathrm{LiCO}_{3}$ ) in aprotic electrolyte [3]. This may clog the porous cathode, resulting in a reduction in three-phase reaction performance [4-9]. The aprotic Li/air battery is mostly subjected to operation in an extremely low relative humidity ( $\mathrm{RH})$ environment to prevent the lithium anode from deterioration [3,8,10-12]. Operation in ambient air becomes an impediment for the practical application of aprotic Li/air batteries.

The aqueous and solid Li/air systems do not have the critical issues observed in the aprotic system [2]. Such an aqueous environment at the air cathode allows the battery discharged products to be soluble, and therefore, the clogging of the air cathode can be alleviated $[2,13]$. The air cathode operated with an aqueous electrolyte can tolerate a humid gas inlet, making the system robust in response to humidity changes of ambient air. A Li/air battery operating with an aqueous electrolyte at the cathode and an aprotic electrolyte at the lithium anode becomes feasible through a ceramic or glassy solid state electrolyte, which is called lithium ion conductive membrane (LICM), acting as a separator to entirely isolate the lithium anode from the aqueous electrolyte while effectively transporting lithium ions [14-20]. A spacer between the LICM and lithium anode may be needed to avoid direct contact and to increase anode stability [21]. These factors become the fundamental design elements in hybrid electrolyte lithium-air batteries (HELAB), with a working principle as shown in Figure 1a.

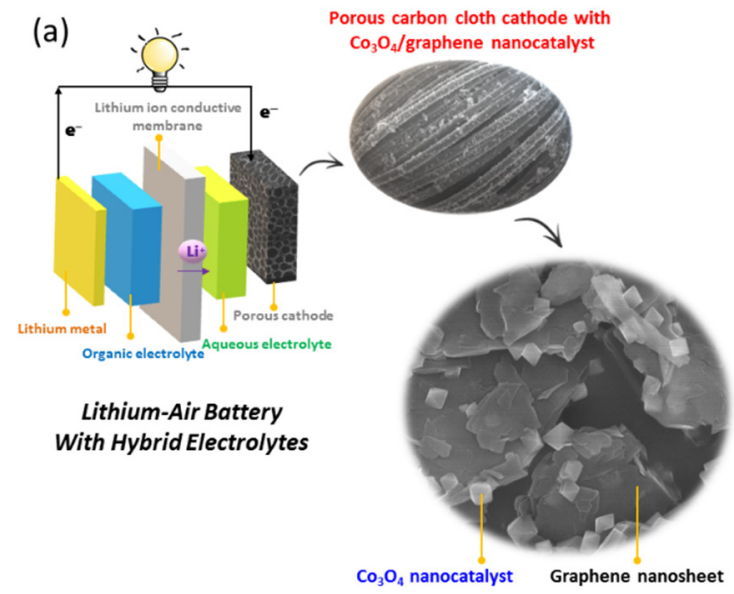

(b)

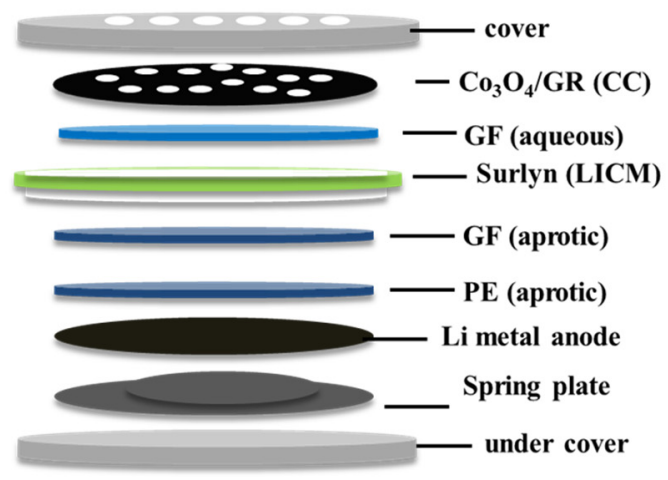

Figure 1. (a) Illustration of hybrid electrolyte lithium-air battery (HELAB) using $\mathrm{Co}_{3} \mathrm{O}_{4} / \mathrm{GR}$ cathode catalyst and (b) assembled HELAB configuration.

Furthermore, an inexpensive, stable bifunctional catalyst for the oxygen reduction reaction (ORR) and the reverse oxygen evolution reaction (OER) at the cathode are essential for a highly efficient battery [22,23]. In the past, conventional platinum catalysts with carbon supports $(\mathrm{Pt} / \mathrm{C})$ are widely employed in Li/air batteries and perform optimally in aprotic Li/air batteries [17,24-27]. However, recent studies have suggested that $\mathrm{Pt} / \mathrm{C}$ catalysts prove to be instable in alkaline systems, such as alkaline fuel cells and HELAB, leading to a decline in battery efficiency and poor battery life [28-32]. As a result, low-cost, stable, and bifunctional catalyst synthesis is crucial to the construction of an efficient HELAB. Among the enormous number of carbon materials, graphene (GR) has attracted enormous attention for its exceptional properties and has been employed in Li/air batteries. Liang et al. showed that a GR support is preferable over other forms of carbon due to higher conductivity, higher surface area, and suitable functional groups for particle anchoring [33]. Sun et al. indicated that a GR-based support is more corrosion-resistant in an alkaline solution than conventional carbon spheres or carbon black [34]. Moreover, cobalt oxide $\left(\mathrm{Co}_{3} \mathrm{O}_{4}\right)$, capable of promoting oxygen reduction reactions (ORRs) and oxygen evolution reactions (OERs), has shown to be the best candidate among the transitional metal oxides [22,35-40] and has potential to replace $\mathrm{Pt} / \mathrm{C}$ catalysts.

Liang et al. and Sun et al. showed that $\mathrm{Co}_{3} \mathrm{O}_{4}$ nanoparticles, a material with little ORR activity if used alone, exhibited surprisingly high performance in both ORR and OER functionalities in alkaline 
solutions when deposited onto reduced graphene oxide or GR $[33,34]$. The $\mathrm{Co}_{3} \mathrm{O}_{4} / \mathrm{GR}$ catalytic activity mechanism in the aprotic lithium-oxygen battery with carbonate-based electrolytes was investigated by $\mathrm{Lim}$ et al. [41]. We recently reported that equal amounts of $\mathrm{Co}_{3} \mathrm{O}_{4}$ and GR are optimal for HELAB cycling performance [42]. In this work, nano-crystalline $\mathrm{Co}_{3} \mathrm{O}_{4}$ formation onto GR is investigated using a two-step process. The physiochemical property changes throughout the synthetic process are elucidated. Catalytic (ORR and OER) and electrochemical characterizations of this $\mathrm{Co}_{3} \mathrm{O}_{4} / \mathrm{GR}$ catalyst are performed. A cathode electrode containing this catalyst is prepared, and the assembled HELAB is validated to exhibit stable and reversible voltaic performance in an air-breathing, humid setting. In addition, a concentrated aqueous electrolyte (saturated $\mathrm{LiOH}$ in $11.6 \mathrm{M} \mathrm{LiCl}$ ) at the cathode is adopted. The resulting HELAB performance using this $\mathrm{Co}_{3} \mathrm{O}_{4} / \mathrm{GR}$ catalyst is discussed.

\section{Materials and Methods}

\subsection{Synthesis of $\mathrm{Co}_{3} \mathrm{O}_{4} / \mathrm{GR}$ Composites}

The graphene sheets employed in this work were obtained from RITEK Corporation (Hsin Chu City, Taiwan). The $\mathrm{Co}_{3} \mathrm{O}_{4} / \mathrm{GR}$ composite was synthesized via a facile two-step method. Approximately $0.1584 \mathrm{~g}$ of graphene was dispersed into $24 \mathrm{~mL}$ of ethanol (Qung Hong International Co., Ltd., Tainan, Taiwan, 95\%), and $1.2 \mathrm{~mL}$ of $2 \mathrm{M}$ aqueous $\mathrm{Co}\left(\mathrm{NO}_{3}\right)_{2} \cdot 6 \mathrm{H}_{2} \mathrm{O}$ solution (purchased from J.T. Baker, Phillipsburg, NJ, USA) was added into the graphene suspension. In the first step, the mixture was heated and stirred at $80{ }^{\circ} \mathrm{C}$ for $4 \mathrm{~h}$ to allow a cobalt intermediate to form on the graphene sheets through a hydrolysis reaction, with the slow addition of $1.2 \mathrm{~mL}$ of water. The resulting mixture was transferred into a $40 \mathrm{~mL}$ Teflon container and placed into a stainless steel autoclave vessel, to proceed to a hydrothermal reaction at $165^{\circ} \mathrm{C}$ for $3 \mathrm{~h}$ to allow the formation of crystalline $\mathrm{Co}_{3} \mathrm{O}_{4}$ and crystal growth on the graphene sheets. The solution was then centrifuged at 10,000 rpm for $20 \mathrm{~min}$ and washed with $95 \%$ ethanol. This centrifugation-washing step was carried out three times. The $\mathrm{Co}_{3} \mathrm{O}_{4} / \mathrm{GR}$ composites were successfully synthesized after drying at $80^{\circ} \mathrm{C}$ overnight.

\subsection{Preparation of Lithium Ion Conductive Membrane (LICM)}

First, $2.8456 \mathrm{~g}$ of $\mathrm{LiOH} \cdot \mathrm{H}_{2} \mathrm{O}$ (Sigma-Aldrich, St. Louis, MO, USA, $\geq 99.0 \%$ ), $18.00 \mathrm{~g}$ of $\mathrm{NH}_{4} \mathrm{H}_{2} \mathrm{PO}_{4}$ (Acros Organics, Geel, Belgium, $99.9 \%$ ), and $5.87 \mathrm{~g}$ of $\mathrm{Al}\left(\mathrm{NO}_{3}\right)_{3} \cdot 9 \mathrm{H}_{2} \mathrm{O}$ (Alfa Aesar, Ward Hill, MA, USA, $98 \%$ ) were added to $200 \mathrm{~mL}, 400 \mathrm{~mL}$, and $150 \mathrm{~mL}$ of ethanol, respectively. Then, $10 \mathrm{~mL}$ and $20 \mathrm{~mL}$ of nitric acid (J.T. Baker, Phillipsburg, NJ, USA, 70\%) were added to the ethanol solutions containing $\mathrm{LiOH}$ and $\mathrm{NH}_{4} \mathrm{H}_{2} \mathrm{PO}_{4}$, respectively. The acidified ethanol solution containing $\mathrm{NH}_{4} \mathrm{H}_{2} \mathrm{PO}_{4}$ was mixed with the ethanol solution containing $\mathrm{Al}\left(\mathrm{NO}_{3}\right)_{3}$ while $16.82 \mathrm{~g}$ of $\mathrm{TiCl}_{4}$ (Sigma-Aldrich, St. Louis, $\mathrm{MO}$, $\mathrm{USA}, \geq 98.0 \%$ ) was added into the acidified ethanol solution containing $\mathrm{LiOH}$. Both solutions were then continuously stirred for $1 \mathrm{~h}$ until complete dissolution. The resulting two clear solutions were mixed through continuous stirring, and the resulting precursor solution was dried in a rotary evaporator at $80{ }^{\circ} \mathrm{C}$ for $3 \mathrm{~h}$. The obtained xerogels were heated at $500{ }^{\circ} \mathrm{C}$ for $5 \mathrm{~h}$, and the resulting precursor powder was then calcined in air at $700{ }^{\circ} \mathrm{C}$ for $2 \mathrm{~h}$ to transform into a crystalline structure. This LATP powder was hand-milled and sieved with a 200 mesh sieve. The as-prepared LATP powder was mixed with polyvinyl alcohol (PVA, Chang Chun Group, Taipei, Taiwan, M.W. 27,000-32,000 Da), poly(oxyethylene) (PEG, Sigma-Aldrich, St. Louis, MO, USA, M.W. 2000 Da), and distilled water (53:2:13:32 w/w). The slurry solution was casted onto a silicon-poly(ethylene) terephthalate release film (H350A, Nanya Technology Corporation, New Taipei City, Taiwan; $50 \mu \mathrm{m}$ thick and $17 \mathrm{~kg} \mathrm{~mm} \mathrm{~m}^{-2}$ in tensile strength) using a film-casting doctor blade. After being dried at room temperature for $12 \mathrm{~h}$, the dried tape film was cut into disks of $18 \mathrm{~mm}$ in diameter, and 3 pieces of these disks were hot pressed at $400 \mathrm{MPa}$ to form a LATP LICM green body. The green body was then dewaxed at $500{ }^{\circ} \mathrm{C}$ for $3 \mathrm{~h}$ and sintered at $900{ }^{\circ} \mathrm{C}$ for $7 \mathrm{~h}$ to obtain a LATP LICM. This LICM had a thickness of $\sim 400 \mu \mathrm{m}$ and a Li-ion conductivity of $10^{-5} \mathrm{~S} \mathrm{~cm}^{-1}$. 


\subsection{Preparation and Characterization of Air Cathode}

Catalyst ink solutions were prepared by mixing the as-prepared $\mathrm{Co}_{3} \mathrm{O}_{4} / \mathrm{GR}$ powder $(60 \mathrm{wt} \%)$ with poly(1,1-difluoroethylene) (PVDF, $40 \mathrm{wt} \%$, from Sigma-Aldrich, St. Louis, MO, USA, M.W. 534,000 Da) binder in N-methyl-2-pyrrolidone (NMP, Macron Fine Chemicals, Radnor, PA, USA, $\geq 99.0 \%$ ) and ultra-sonicating for $1 \mathrm{~h}$. The air cathode was prepared by immersing a carbon cloth (CeTech Co., Ltd. Taichung, Taiwan, $0.33 \mathrm{~mm}$ in thickness with a plane resistance of less than $5 \mathrm{~m} \Omega \mathrm{cm}^{-2}$ ) into the catalyst ink solution in an ultrasonic bath for $0.5 \mathrm{~h}$ and dried at $120^{\circ} \mathrm{C}$. The air cathode area was $2.01 \mathrm{~cm}^{2}$, and the mass loading of the $\mathrm{Co}_{3} \mathrm{O}_{4} / \mathrm{GR}$ catalyst was approximately $1 \mathrm{mg}$ of active ingredient $\left(\mathrm{Co}_{3} \mathrm{O}_{4}\right.$ plus GR) per $\mathrm{cm}^{2}$.

The microstructure of the $\mathrm{Co}_{3} \mathrm{O}_{4} / \mathrm{GR}$ nanocatalysts and electrodes was examined using a scanning electron microscope (SEM, Type N, Hitachi Ltd., Tokyo, Japan) or field-emission scanning electron microscope (FE-SEM, SU8000, Hitachi Ltd., Tokyo, Japan) operated at $15 \mathrm{kV}$. Energy-dispersive X-ray spectroscopy (EDX) was performed with an Xflash Detector 5030 (Bruker AXS GmbH, Karlsruhe, Germany). X-ray diffraction (XRD) patterns were recorded on a Bruker D2 Phaser (Bruker AXS GmbH, Karlsruhe, Germany) with $\mathrm{Cu} \mathrm{K} \alpha$ radiation $\left(\lambda=1.54 \AA\right.$ ) over the $2 \theta$ range of $10^{\circ}$ to $80^{\circ}$ for catalysts and electrodes. Thermo-gravimetric analysis (TGA) was carried out using a Q50 (TA Instrument, New Castle, DE, USA). The porous structures of the $\mathrm{Co}_{3} \mathrm{O}_{4} / \mathrm{GR}$ nanocatalysts and electrodes were analyzed using a porosimetry analyzer (ASAP 2020, Micromeritics Instrument Corp., Norcross, GA, USA) to report Brunauer-Emmett-Teller (BET) specific surface areas. A Raman spectrometer (UniDRON, CL Technology Co., Ltd., New Taipei City, Taiwan) was employed to examine the carbon bond structure. The green laser beam (532 nm wavelength excited at $50 \mathrm{~mW}$ ) was focused using an objective lens (Olympus, magnification of 50, numerical aperture $\sim 0.55$ ), and all spectra were collected under the accumulation mode with a $1 \mathrm{~s}$ acquisition time. The electrical sheet resistance for the air cathode was measured using a four-point probe (MCP-T600, Mitsubishi Chemical Corp., Tokyo, Japan) with a probe distance of $1 \mathrm{~mm}$. All the results were reported in units of ohm/ $\square$.

\subsection{Electrochemical and Battery Performance Measurements}

An organic liquid electrolyte, $1 \mathrm{M}$ lithium bis(trifluoromethanesulfonyl)imide (LiTFSI, Ionic Liquids Technologies, Heilbronn, Germany, 99.0\%) in tetra ethylene glycol dimethyl ether (TEGDME, Sigma-Aldrich, St. Louis, MO, USA, $\geq 99.0 \%$ ), was prepared as the aprotic organic electrolyte. The synthesized LATP LICM was employed as the separator between the Li anode and air cathode. The aqueous electrolyte solution consisted of a $5.8 \mathrm{M} \mathrm{LiCl}$ (Alfa Aesar, Haverhill, MA, USA, 99.0\%) and $2.55 \mathrm{M} \mathrm{LiOH}$ (Sigma-Aldrich, St. Louis, MO, USA, $\geq 99.0 \%$ ) mixture. Another concentrated, saturated $\mathrm{LiOH}$ in $11.6 \mathrm{M} \mathrm{LiCl}$ solution was prepared by continuously adding $\mathrm{LiOH}$ into $11.6 \mathrm{M} \mathrm{LiCl}$ aqueous solution until precipitates formed, and the saturated solution was filtered through a filter paper (Whatman plc, Maidstone, UK).

The hybrid electrolyte Li-air battery (HELAB) was assembled in CR-2032 coin cells (X2 Labwares Pte Ltd., Shenton House, Singapore) in a glove box (Unilab 3306-A, MBRAUN, Stratham, NH, USA). A polyethylene (PE) separator (Celgard, Charlotte, NC, USA, $25 \mu \mathrm{m}$ in thickness) was immersed in the organic liquid electrolyte for $24 \mathrm{~h}$. Two pieces of glass fiber (GF) separator (Whatman, Maidstone, UK, $420 \mu \mathrm{m}$ in thickness) or polypropylene (PP) separator (NKK Switches Co. Ltd., N.T., Hong Kong, $100 \mu \mathrm{m}$ in thickness) were immersed in the organic liquid electrolyte (as anolyte) and aqueous liquid electrolyte (as catholyte) for $24 \mathrm{~h}$, respectively. The LICM was glued with a hollow Surlyn membrane (Surlyn 1706, DuPont de Nemours, Inc., Wilmington, DE, USA) on the brink for the complete insulation of electrolyte crossover. The HELAB was constructed by assembling an air cover (with holes), air electrode, aqueous electrolyte-impregnated PP or GF, LICM, organic electrolyte-impregnated PP or GF, organic electrolyte-impregnated PE, lithium foil ( $0.2 \mathrm{~mm}$ thick), spring leaf, and anode cell base (Figure 1b) and crimping to enclose the battery. The coin battery was placed into a bottle with a built-in clip-on test module. The assembled battery was exposed to ambient air of $70-100 \%$ relative humidity for testing. Autolab (PGSTAT-30 Eco Chemie B. V., Utrecht, The Netherlands) was used to carry out 
linear sweep voltammetry (LSV), and the scan rate was $100 \mathrm{mV} \mathrm{s}^{-1}$ for ORR and OER measurements. Discharge/charge cycling was performed using a test station (Model BAT-750B, AcuTech System Co. Ltd., New Taipei City, Taiwan) and operated a 2-4.5 V voltage limits at a current of $0.1 \mathrm{~mA}$ (i.e., current density of $0.05 \mathrm{~mA} \mathrm{~cm}^{-2}$ ), with a $2 \mathrm{~h}$ discharge and $2 \mathrm{~h}$ charge time and $10 \mathrm{~min}$ break between cycles.

\section{Results and Discussion}

\subsection{Characterization of Synthesized $\mathrm{Co}_{3} \mathrm{O}_{4} / \mathrm{GR}$ Composite}

FE-SEM and XRD were used to determine the morphological and crystalline properties of prepared samples throughout the process. The initial GR sheet structure was of micron-meter size (Figure 2a) with a characteristic graphite-like structure (Figure 2d). After the first hydrolysis reaction step at $80{ }^{\circ} \mathrm{C}$, there were no significant morphological changes in the GR sheets (Figure 2b), but the GR transformed into an amorphous form (Figure 2d). Moreover, there was a significant cobalt signal from EDX mapping (Figure S1), implying that an intermediate might have formed and acted as nucleation sites on the GR sheet (Figure 2e). After hydrothermal treatment at $165^{\circ} \mathrm{C}$, the particle crystals formed significantly, and these octahedral particles ranged from 100 to $300 \mathrm{~nm}$ (Figure 2c). The hydrothermal process promoted both GR and $\mathrm{Co}_{3} \mathrm{O}_{4}$ crystallization. The XRD pattern of the $\mathrm{Co}_{3} \mathrm{O}_{4} / \mathrm{GR}$ composite clearly indicates that the crystals consisted of graphite and $\mathrm{Co}_{3} \mathrm{O}_{4}$ structure (as shown in Figure $2 \mathrm{f}$ ). Ehrhardt et al. indicated that $\mathrm{Co}_{2} \mathrm{O}_{3}$ and $\mathrm{Co}_{3} \mathrm{O}_{4}$ were likely to form simultaneously [43]. However, our sample was indexed to be mainly $\mathrm{Co}_{3} \mathrm{O}_{4}$ (with $2 \theta=19.0^{\circ}, 36.9^{\circ}$, and $44.8^{\circ}$ as described in PDF \#42-1467) without the formation of $\mathrm{Co}_{2} \mathrm{O}_{3}$ (whose XRD patterns are shown at $2 \theta=51.2^{\circ}, 56.3^{\circ}$, and $67.3^{\circ}$ as described in PDF \#02-0770 [44]). These results indicated that the hydrolysis reaction enabled the cobalt compound's nucleation onto the GR sheets. The hydrothermal reaction allowed these nucleation sites to grow. Therefore, the hydrothermal step was crucial for forming crystalline $\mathrm{Co}_{3} \mathrm{O}_{4}$ particles The $\mathrm{Co}_{3} \mathrm{O}_{4}$ crystalline size was evaluated to be $73.1 \mathrm{~nm}$ using Scherrer's formula $(D=0.9 \times \lambda / \beta \times \cos \theta)$ at $2 \theta=36.9^{\circ}$ (Table 1$)$.
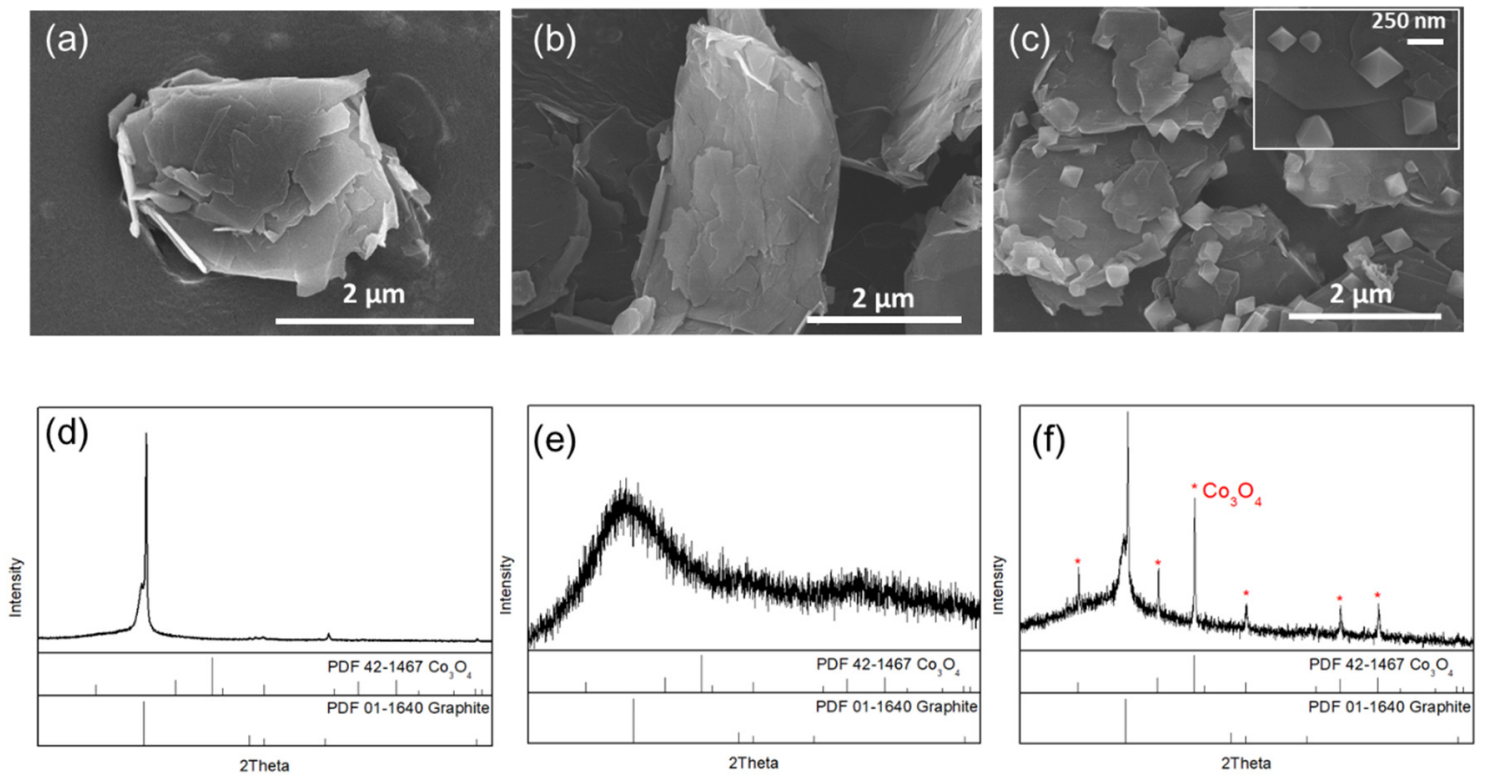

Figure 2. Morphological and crystalline properties of the initial graphene (GR), intermediate after $80^{\circ} \mathrm{C}$ hydrolysis, and $\mathrm{Co}_{3} \mathrm{O}_{4} / \mathrm{GR}$ composite synthesized after the $165^{\circ} \mathrm{C}$ hydrothermal process: (a-c) SEM images and (d-f) XRD patterns of $\mathrm{Co}_{3} \mathrm{O}_{4} / \mathrm{GR}$ composites at different states: (a,d) initial GR sheets, $(\mathbf{b}, \mathbf{e})$ after the hydrolysis reaction, and $(\mathbf{c}, \mathbf{f})$ after the hydrothermal reaction. 
Table 1. Crystalline size and Brunauer-Emmett-Teller (BET) results for raw graphene (GR) support and as-prepared $\mathrm{Co}_{3} \mathrm{O}_{4}$ /graphene composites containing $48.2 \mathrm{wt} \% \mathrm{Co}_{3} \mathrm{O}_{4}$.

\begin{tabular}{|c|c|c|c|c|}
\hline Property & $\begin{array}{l}\text { Crystalline Size } \\
\text { (nm) }\end{array}$ & $\begin{array}{l}\text { Surface Area } \\
\qquad\left(\mathrm{m}^{2} \mathrm{~g}^{-1}\right)\end{array}$ & $\begin{array}{l}\text { Pore Volume } \\
\qquad\left(\mathrm{cm}^{3} \mathrm{~g}^{-1}\right)\end{array}$ & Pore Size (̊̊) \\
\hline Raw GR & $-{ }^{a}$ & 18.8 & 0.0475 & 101 \\
\hline $\mathrm{Co}_{3} \mathrm{O}_{4} / \mathrm{GR}$ & 73.1 & 14.2 & 0.0311 & 87.5 \\
\hline
\end{tabular}

${ }^{\mathrm{a}}$ Not applicable.

The $\mathrm{Co}_{3} \mathrm{O}_{4}$ loading in the $\mathrm{Co}_{3} \mathrm{O}_{4} / \mathrm{GR}$ composite was confirmed from thermogravimetric analysis. The pristine GR was completely decomposed at $700{ }^{\circ} \mathrm{C}$; therefore, the remaining mass would be from $\mathrm{Co}_{3} \mathrm{O}_{4}$. This $\mathrm{Co}_{3} \mathrm{O}_{4}$ loading was calculated to be $48.2 \mathrm{wt} \%$ (Figure 3a). The BET was used to examine the pore properties of the raw graphene sheets and prepared $\mathrm{Co}_{3} \mathrm{O}_{4} / \mathrm{GR}$ composite, and the surface area, pore volume, and pore size were all decreased (Table 1) as $\mathrm{Co}_{3} \mathrm{O}_{4}$ was deposited onto the graphene sheets. These results indicated that $\mathrm{Co}_{3} \mathrm{O}_{4}$ growth likely influenced the graphene sheet, diminishing the graphene microporous properties owing to $\mathrm{Co}_{3} \mathrm{O}_{4}$ occupation and possibly suffering defects, as the surface area had a nearly $24 \%$ reduction, as well as $34 \%$ and $13 \%$ declines in pore volume and pore size, respectively. The resulting sample specific surface area was found to be much smaller than the reported graphene value (up to $2630 \mathrm{~m}^{2} / \mathrm{g}$ in monolayer graphene [45]). This may be attributed to the agglomeration of drying graphene, leading to a substantial reduction in specific surface area. Esmaeili et al. reported that the specific surface area of graphene oxide ranged from 2 to $1000 \mathrm{~m}^{2} \mathrm{~g}^{-1}$, which is much lower than expected, owing to agglomeration throughout the drying process [46-48]. The specific surface area of the $\mathrm{Co}_{3} \mathrm{O}_{4} / \mathrm{GR}$ composite was further reduced from that of the pristine GR due to GR sheet stacking, as indicated by the 2D band increase in the Raman spectrum in the next paragraph.
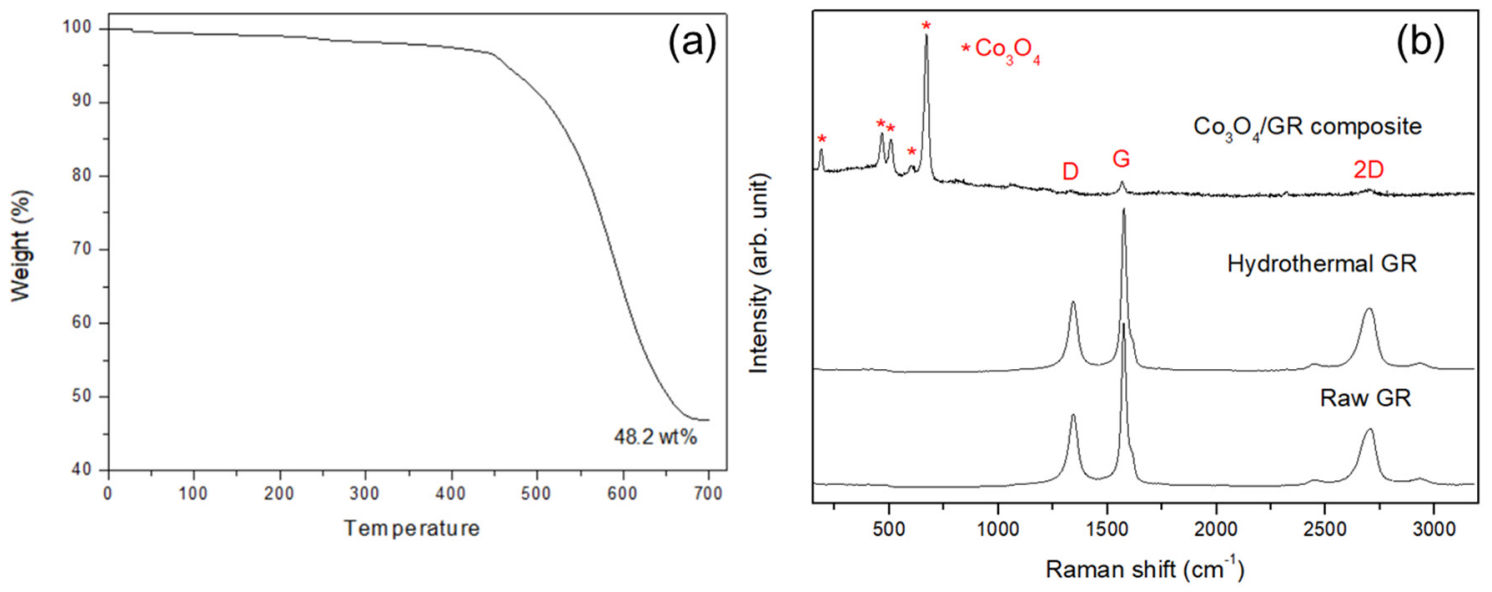

Figure 3. (a) Thermo-gravimetric analysis (TGA) results for the as-prepared $\mathrm{Co}_{3} \mathrm{O}_{4} / \mathrm{GR}$ composite, and (b) Raman spectra of the pristine GR sheets, hydrothermal treated GR, and $\mathrm{Co}_{3} \mathrm{O}_{4} / G R$ composite.

Raman spectroscopy was utilized to characterize prepared samples and clarified the interaction of GR and cobalt precursor at high temperature. According to the Raman spectra, the prepared sample was confirmed to be a $\mathrm{Co}_{3} \mathrm{O}_{4} / \mathrm{GR}$ composite [49]; the characteristic Raman bands for $\mathrm{Co}_{3} \mathrm{O}_{4}$ positioned at $475 \mathrm{~cm}^{-1}, 518 \mathrm{~cm}^{-1}$, and $682 \mathrm{~cm}^{-1}$ were prominent (Figure $3 \mathrm{~b}$ ), which is in line with the aforementioned XRD analysis. $\mathrm{Co}_{3} \mathrm{O}_{4}$ was identified as the main phase because there were nearly no characteristic cobalt hydroxide $\mathrm{Co}(\mathrm{OH})_{2}$ bands present at $219 \mathrm{~cm}^{-1}$ and $1068 \mathrm{~cm}^{-1}$ [50]. From the Raman analysis, it is clear that the chosen hydrothermal temperature $\left(165^{\circ} \mathrm{C}\right)$ largely prevented impurity $\left(\mathrm{Co}(\mathrm{OH})_{2}\right)$ formation. Moreover, the $\mathrm{Co}_{3} \mathrm{O}_{4}$ particle deposition hardly increased GR sheet defects, as evident from the similar $\mathrm{I}_{\mathrm{D}} / \mathrm{I}_{\mathrm{G}}$ ratio (Table 2 ). The $2 \mathrm{D}$ band signal increased significantly $(p<0.05)$, indicating more GR stacking in the $\mathrm{Co}_{3} \mathrm{O}_{4} / \mathrm{GR}$ composite. 
Table 2. The Raman peaks of the D band, G band, and 2D band for the raw graphene (GR) sheets, hydrothermally treated GR sheets, and $\mathrm{Co}_{3} \mathrm{O}_{4} / \mathrm{GR}$ composite.

\begin{tabular}{cccccc}
\hline Sample & $\begin{array}{c}\text { D Band } \\
\left(\mathbf{c m}^{-\mathbf{1}}\right)\end{array}$ & $\begin{array}{c}\text { G Band } \\
\left(\mathbf{c m}^{-\mathbf{1}} \mathbf{)}\right.\end{array}$ & $\begin{array}{c}\text { 2D Band } \\
\left(\mathbf{c m}^{-\mathbf{1}} \mathbf{)}\right.\end{array}$ & $\mathbf{I}_{\mathbf{D}} / \mathbf{I}_{\mathbf{G}}$ & $\mathbf{I}_{\mathbf{2}} / \mathbf{I}_{\mathbf{G}}$ \\
\hline Raw GR & 1343 & 1574 & 2708 & $0.44 \pm 0.02$ & $0.35 \pm 0.04$ \\
Hydrothermal GR & 1343 & 1576 & 2701 & 0.42 & 0.38 \\
$\mathrm{Co}_{3} \mathrm{O}_{4} /$ GR composite & 1338 & 1566 & 2694 & $0.47 \pm 0.04$ & $0.51 \pm 0.04$ \\
\hline
\end{tabular}

\subsection{Prepared Air Cathode Characterization}

Carbon cloth was chosen as substrate for the air cathode and the as-prepared $\mathrm{Co}_{3} \mathrm{O}_{4} / G R$ composite loaded onto carbon cloth. The electrical resistance value of the pristine carbon cloth was $0.1285 \Omega$ and slightly increased after binder (PVDF) coating, along with a mild thickness increase (from approximately $373 \mu \mathrm{m}$ to $397 \mu \mathrm{m})$. The electrical resistance of the PVDF-coated carbon cloth dried at $120^{\circ} \mathrm{C}$ was lower than those at 80 and $100{ }^{\circ} \mathrm{C}$ (Table 3). SEM and XRD were employed to ensure that the $\mathrm{Co}_{3} \mathrm{O}_{4} / \mathrm{GR}$ composite was sprayed onto the carbon cloth. The SEM images (Figure $4 \mathrm{a}-\mathrm{c}$ at different magnifications) showed that the $\mathrm{Co}_{3} \mathrm{O}_{4} / \mathrm{GR}$ composite was distributed onto the carbon cloth. Figure 4 a shows that the carbon cloth contained a woven-like structure with visible porosity. Figure $4 \mathrm{~b}$ shows that the thickness of the carbon fibers was approximately $10 \mu \mathrm{m}$ and that the catalytic materials were grafted on the carbon fibers. Moreover, the embedded catalytic materials on the cathode displayed the same crystal pattern as the $\mathrm{Co}_{3} \mathrm{O}_{4} / \mathrm{GR}$ composite (Figure $4 \mathrm{c}$ ). The XRD of the $\mathrm{Co}_{3} \mathrm{O}_{4} / \mathrm{GR}$ composite (Figure $4 \mathrm{~d}$ ) exhibited additional signals on top of those of the carbon cloth and demonstrated $\mathrm{Co}_{3} \mathrm{O}_{4}$ (PDF \#42-1467) and GR sheets (PDF \#01-1640), respectively.
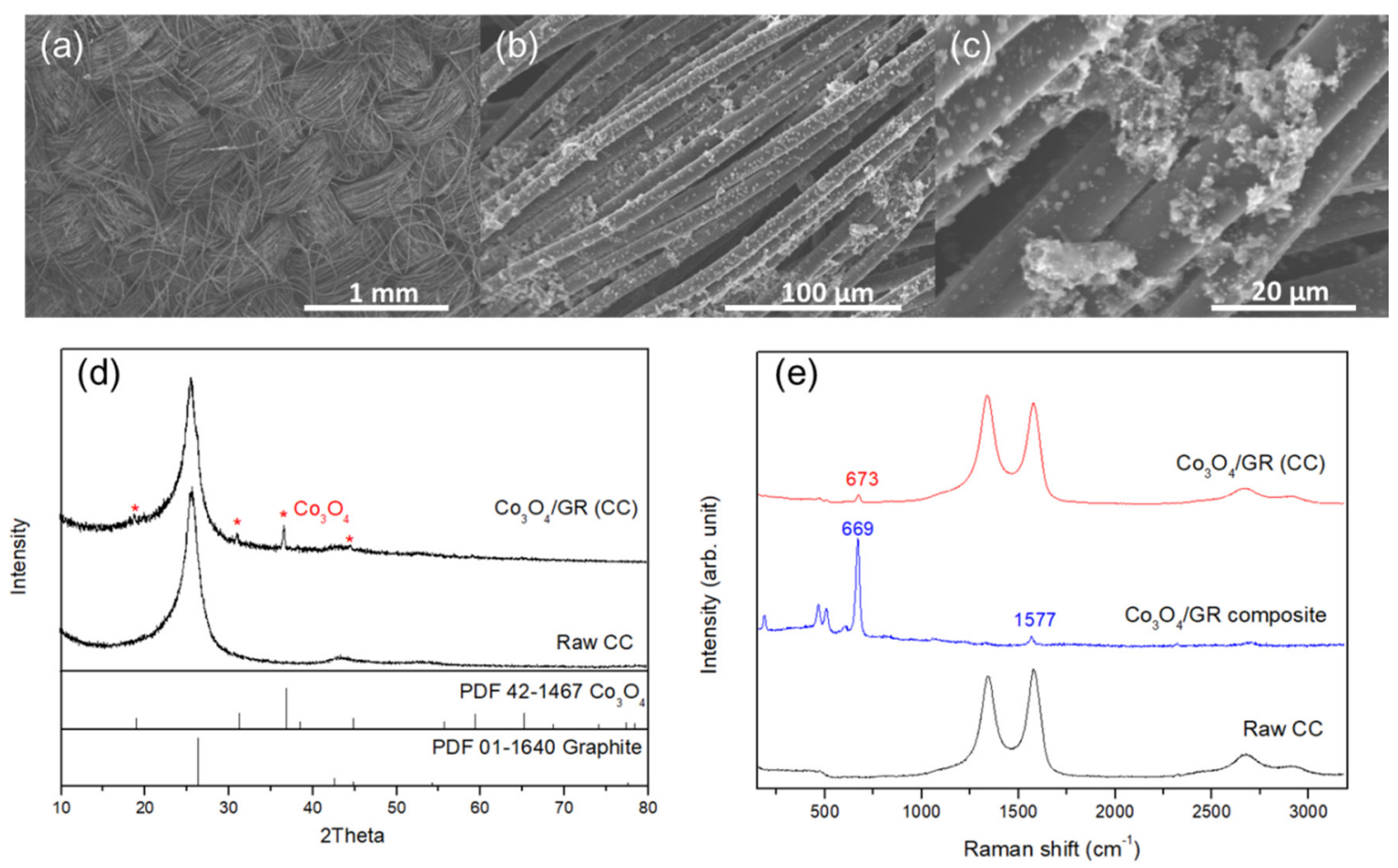

Figure 4. (a-c) SEM images at different magnifications of the air cathode consisting of carbon cloth loaded with the $\mathrm{Co}_{3} \mathrm{O}_{4} / \mathrm{GR}$ composite, (d) XRD patterns of the as-prepared air cathode with or without the $\mathrm{Co}_{3} \mathrm{O}_{4} / \mathrm{GR}$ composite, and (e) Raman spectra of the raw carbon cloth (CC), $\mathrm{Co}_{3} \mathrm{O}_{4} / \mathrm{GR}$ composite, and carbon cloth (CC) with the $\mathrm{Co}_{3} \mathrm{O}_{4} / \mathrm{GR}$ composite.

In addition, Raman spectroscopy was employed to identify the prepared air cathode. The raw carbon cloth showed a similar Raman spectrum to that of GR (Figure $3 \mathrm{~b}$ or Figure 4e). The $\mathrm{Co}_{3} \mathrm{O}_{4} / \mathrm{GR}$ composite spectrum exhibited dominant $\mathrm{Co}_{3} \mathrm{O}_{4}$ peaks, indicating the strong crystallinity of $\mathrm{Co}_{3} \mathrm{O}_{4}$, 
resulting in the suppression of GR peak intensities. The similar findings of GR signal suppression in composites were also reported in the literature [51-53]. The air cathode showed Raman peaks from both the $\mathrm{Co}_{3} \mathrm{O}_{4} / \mathrm{GR}$ composite and raw carbon cloth signals (Figure 4e). Therefore, the carbon cloth with the $\mathrm{Co}_{3} \mathrm{O}_{4} / \mathrm{GR}$ composite was proven to be successfully prepared via multiple instrumental analyses. Moreover, the air cathode had a significant reduction in electrical resistance of $53-60 \%$, with an increased thickness of $419 \mu \mathrm{m}$, in comparison with the pristine carbon cloth (Table 3), which was attributed to the excellent GR sheet electrical properties. This illustrated that GR sheets within the $\mathrm{Co}_{3} \mathrm{O}_{4} / \mathrm{GR}$ composite in fact maintained its exceptional properties as an electrical conductive material.

Table 3. Electrical resistance of air electrodes produced using various compositions and drying temperatures.

\begin{tabular}{ccc}
\hline Air Cathode & Thickness $(\mu \mathbf{m})$ & Sheet Resistance (ohm/ $\square)$ \\
\hline Raw carbon cloth & 373 & 0.541 \\
Carbon cloth (PVDF) dried at $80{ }^{\circ} \mathrm{C}$ & 397 & 0.906 \\
Carbon cloth $(\mathrm{PVDF})$ dried at $100^{\circ} \mathrm{C}$ & 397 & 0.918 \\
Carbon cloth $(\mathrm{PVDF})$ dried at $120{ }^{\circ} \mathrm{C}$ & 397 & 0.821 \\
Carbon cloth (PVDF $\left.+\mathrm{Co}_{3} \mathrm{O}_{4} / \mathrm{GR}\right)$ dried at $120^{\circ} \mathrm{C}$ & 419 & $0.325-0.386$ \\
\hline
\end{tabular}

\subsection{Cathode Catalytic Performance and HELAB Cycling Performance}

A HELAB employing the developed cathode was assembled (with the configuration shown in Figure 1b) and proved rechargeable when fed with ambient air with high humidity of $70-100 \%$. In addition, the air cathode's ORR and OER functionalities were investigated by LSV tests (Figure 5). The $\mathrm{Co}_{3} \mathrm{O}_{4} / \mathrm{GR}$ composite was dip-coated onto carbon cloth to prepare the air cathode (denoted as $\left.\mathrm{Co}_{3} \mathrm{O}_{4} / \mathrm{GR}(\mathrm{CC})\right)$ of $1 \mathrm{mg} \mathrm{cm}^{-2}$ of active ingredient $\left(\mathrm{Co}_{3} \mathrm{O}_{4}\right.$ plus GR). The pristine carbon cloth air cathode was selected for comparison (denoted as CC). For ORR capability (Figure 5a), the HELAB with $\mathrm{Co}_{3} \mathrm{O}_{4} / \mathrm{GR}(\mathrm{CC})$ had apparently higher induced currents at any given potential than that of the HELAB with CC. At the limiting voltage of $1.5 \mathrm{~V}$, the induced current was $3.77 \mathrm{~mA}$ for the HELAB with $\mathrm{Co}_{3} \mathrm{O}_{4} / \mathrm{GR}(\mathrm{CC})$, which was 2.56 times that of the HELAB with CC. For OER ability (Figure 5b), the HELAB with $\mathrm{Co}_{3} \mathrm{O}_{4} / \mathrm{GR}(\mathrm{CC})$ had a considerably more negative OER onset potential (shifted from $3.82 \mathrm{~V}$ to $3.64 \mathrm{~V}$ ) and higher induced currents at any given potential. At the limiting voltage of $4.5 \mathrm{~V}$, the induced current was $0.434 \mathrm{~mA}$ for the HELAB with $\mathrm{Co}_{3} \mathrm{O}_{4} / \mathrm{GR}(\mathrm{CC})$, which was 17.36 times that of the HELAB with CC.
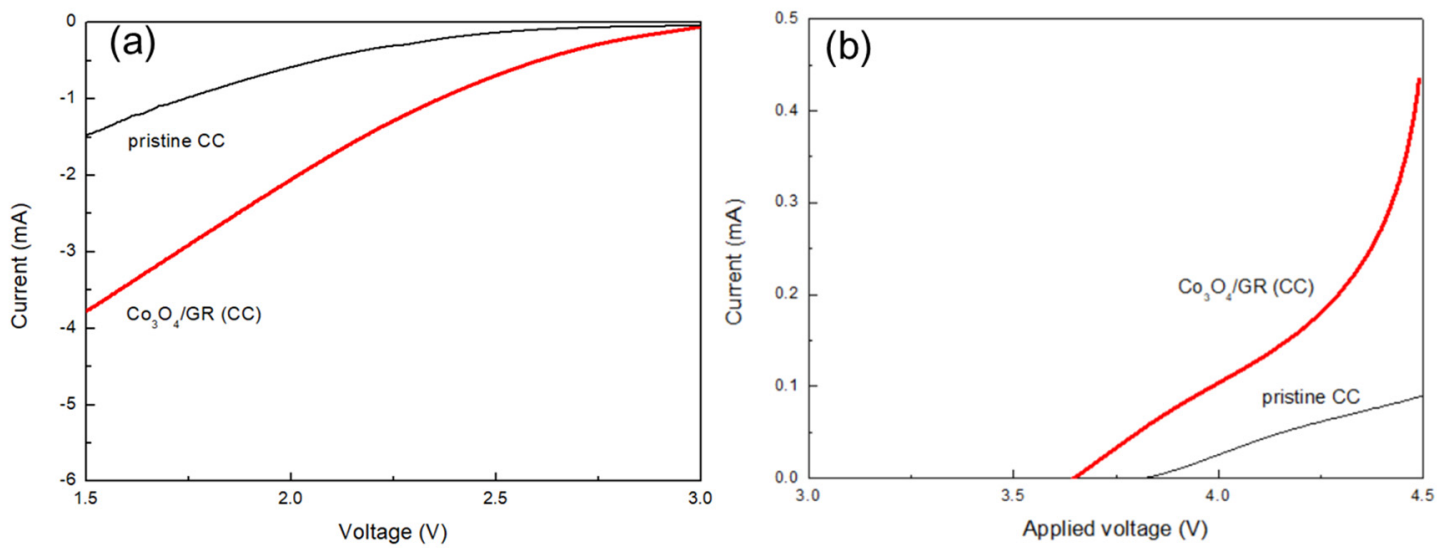

Figure 5. The linear sweep voltammetry (LSV) tests for HELABs with the air cathode of $\mathrm{Co}_{3} \mathrm{O}_{4} / \mathrm{GR}$ (CC), along with the control pristine carbon cloth (CC) on (a) oxygen reduction reaction and (b) oxygen evolution reaction, respectively.

The LSV showed that the HELAB with $\mathrm{Co}_{3} \mathrm{O}_{4} / \mathrm{GR}(\mathrm{CC})$ displayed better ORR and OER capabilities than those of the HELAB with CC, especially demonstrating a much better OER capability of the 
HELAB. It could be ascribed to the higher OER ability of $\mathrm{Co}_{3} \mathrm{O}_{4} / \mathrm{GR}$ than that of carbon cloth. As pointed out in another study [42], the catalytic $\mathrm{Co}_{3} \mathrm{O}_{4}$ benefits reactions and GR assists charge transfer. The combination of these two components improved the ORR and OER functionalities more than the individual ingredients $[33,34,42]$. These results pointed out that the addition of the $\mathrm{Co}_{3} \mathrm{O}_{4} / \mathrm{GR}$ composite largely overcame this deficiency but also fortified the ORR/OER capability.

This battery was able to achieve a total capacity of $5385 \mathrm{mAh} \mathrm{g}^{-1}$ [42], which is equivalent to an energy density of $52.3 \mathrm{~kJ}$ per gram of active cathode material. For cycling performance (Figure 6), the HELAB with $\mathrm{Co}_{3} \mathrm{O}_{4} / \mathrm{GR}(\mathrm{CC})$ displayed a much lower over-potential of $1279 \mathrm{mV}$ on cycle 1 than that of HELAB with CC $(1945 \mathrm{mV})$ as shown in Figure 6a. The overall over-potential was cut down by $34 \%$. Besides, the HELAB had a much better discharge/charge plateau; especially, the equilibrium of the charge state was much expedited with the addition of $\mathrm{Co}_{3} \mathrm{O}_{4} / \mathrm{GR}(\mathrm{CC})$. The HELAB with $\mathrm{Co}_{3} \mathrm{O}_{4} / \mathrm{GR}(\mathrm{CC})$ maintained its full capacity on cycle 3 , with a mild increase in over-potential of $27 \%$. For the HELAB with CC, the capacity failed on cycle 3 due to a forwardly aggravated polarization on charge state, leading to a $34 \%$ capacity loss on aggregate (Figure $6 \mathrm{~b}$ ). The considerable enhancement in OER capability in cycling performance was consistent with the LSV test results. These results elucidated that the $\mathrm{Co}_{3} \mathrm{O}_{4} / \mathrm{GR}$ composite was highly beneficial to a carbonaceous substrate air cathode, especially for boosting the OER property. The extended cycling profile further indicated the considerably improved charge ability for HELAB after the $\mathrm{Co}_{3} \mathrm{O}_{4} / \mathrm{GR}$ composite was employed (Figure $6 \mathrm{~d}$ ). The HELAB without the $\mathrm{Co}_{3} \mathrm{O}_{4} / \mathrm{GR}$ catalyst showed a high charge voltage ( $\sim 500 \mathrm{mV}$, Figure $\left.6 \mathrm{c}\right)$, whereas incorporating $\mathrm{Co}_{3} \mathrm{O}_{4} / \mathrm{GR}$ could reduce the charge voltage to below $4500 \mathrm{mV}$ (Figure 6d). In addition, the HELAB with the $\mathrm{Co}_{3} \mathrm{O}_{4} / \mathrm{GR}$ composite maintained its full charge capacity until the 15th cycle $(60 \mathrm{~h})$, demonstrating that our catalytic material not only served as a bi-functional catalyst but also was especially critical for a longer cycling life with full capacity retained.
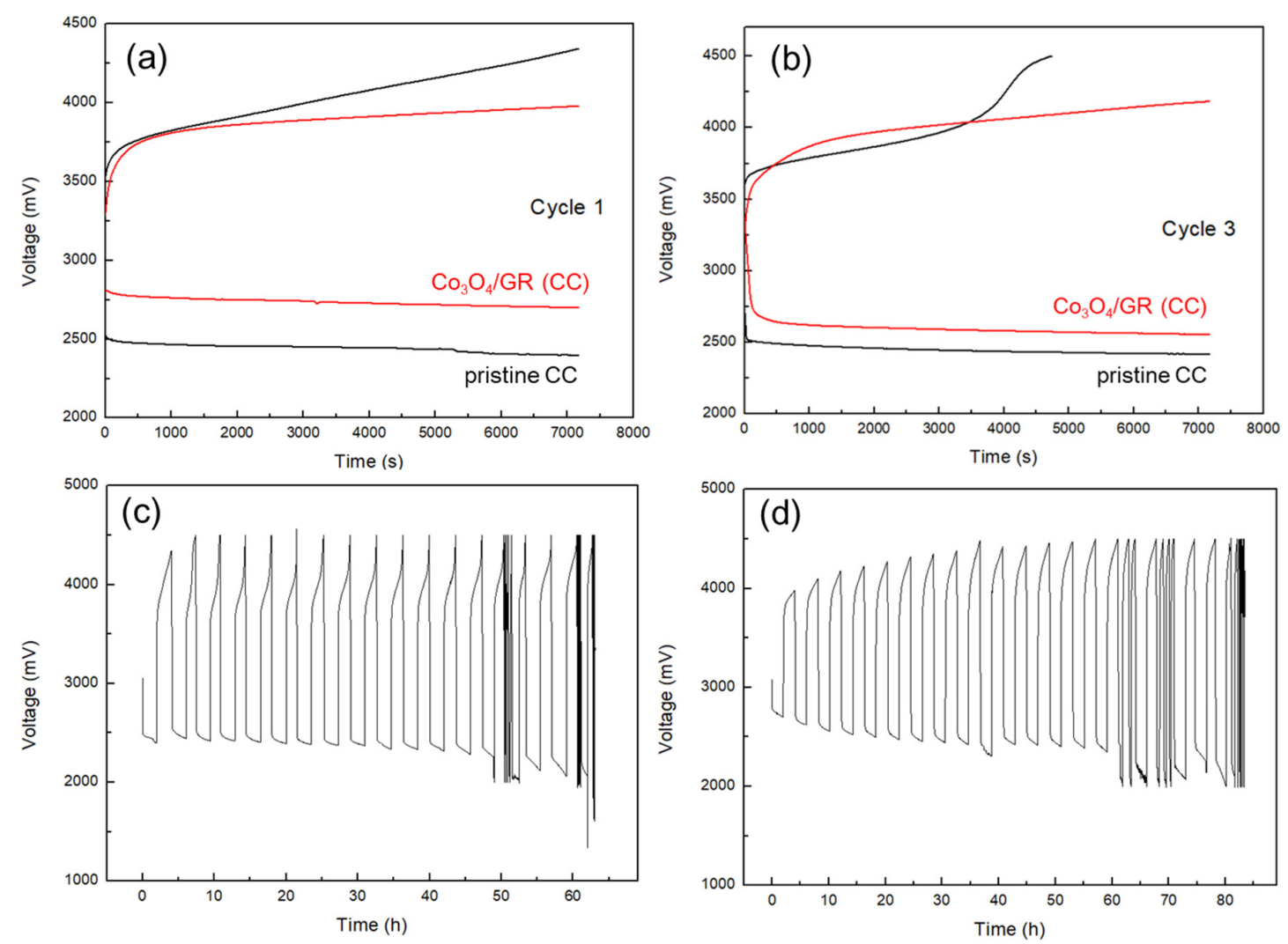

Figure 6. The discharge/charge voltage profiles for HELABs with an air cathode of $\mathrm{Co}_{3} \mathrm{O}_{4} / G R(C C)$, along with control pristine CC on (a) cycle 1 and (b) cycle 3. (c) The cycling voltage profiles for HELABs containing a carbon cloth (CC) cathode without and (d) with $\mathrm{Co}_{3} \mathrm{O}_{4} / \mathrm{GR}$. All the batteries were operated at $0.05 \mathrm{~mA} \mathrm{~cm}^{-2}$ under ambient air with a limited capacity of $100 \mathrm{mAh} \mathrm{g}^{-1}$. 
Current non-aqueous Li/air batteries had a poor cycle life under ambient air in general. Although Wang et al. [8] proposed an advanced non-aqueous Li/air battery that enabled a stale cycle performance of 610 cycles $(610 \mathrm{~h})$ under ambient air, it was restricted to a limited relative humidity of $5 \%$. When the humidity increased to 50\%, the cycle life shortened to 310 cycles ( $310 \mathrm{~h}$ ) [8]. Our HELAB could be directly operated when fed with ambient air with high relative humidity of $70 \%-100 \%$, and a longer cycle life ( $80 \mathrm{~h}$ vs. $60 \mathrm{~h}$ ) was achieved after the $\mathrm{Co}_{3} \mathrm{O}_{4} / \mathrm{GR}$ composite was employed than that without the $\mathrm{Co}_{3} \mathrm{O}_{4} / \mathrm{GR}$ composite (Figure 6c,d). However, attention should be paid to the stability of the lithium-ion conducting solid electrolyte for the consideration of a longer cycle life.

\subsection{Optimization of HELAB Using Saturated LiOH in $11.6 \mathrm{M} \mathrm{LiCl}$}

In a recent review, Lai et al. [13] reported that the addition of $\mathrm{LiCl}$ was used to adjust the alkalinity and increase the conductivity of a $\mathrm{LiOH}$ solution, while Adam et al. [54] proposed that the excessive concentration of $\mathrm{Li}^{+}$may impede the activity of cathodic catalysts. Additionally, the saturated $\mathrm{LiOH}$ in $11.6 \mathrm{M} \mathrm{LiCl}$ was chosen as aqueous electrolyte for comparison with $5.8 \mathrm{M} \mathrm{LiCl}-2.55 \mathrm{M} \mathrm{LiOH}$. The HELAB voltage profiles employing two electrolytes are shown in Figure 7. The HELAB employing the saturated $\mathrm{LiOH}$ in $11.6 \mathrm{M} \mathrm{LiCl}$ displayed a very low over-potential of $543 \mathrm{mV}$, compared to that of the unsaturated aqueous solution $(1404 \mathrm{mV})$. The over-potential was drastically reduced by nearly $61 \%$, reaching a round-trip efficiency of $83 \%$. This considerable improvement is attributed to the saturated $\mathrm{LiOH}$ in $11.6 \mathrm{M} \mathrm{LiCl}$ solution, making the charging reaction occur much more easily. A previous study [55] discovered that a high concentration of lithium ions would suppress the dissociation of $\mathrm{LiOH}$ to the ions of $\mathrm{Li}^{+}$and $\mathrm{OH}^{-}$. Apart from supplementing $\mathrm{Li}^{+}$, Adam's results also indicated that the use of $\mathrm{LiCl}$ can mediate $\mathrm{Li}_{2} \mathrm{CO}_{3}$ formation [54]; however, the role of $\mathrm{Cl}^{-}$is still unclear at this state. The $\mathrm{pH}$ value of our saturated $\mathrm{LiOH}$ in $11.6 \mathrm{M} \mathrm{LiCl}$ was measured to be 9.43 , so the reaction product $\mathrm{LiOH}$ does not dissociate to ions in the $\mathrm{LiCl}$ saturated aqueous solution. Thus, the necessary reactant of the non-dissociated state $\mathrm{LiOH}$ was sufficient in the aqueous electrolyte for the charge reaction. Then, the charge reaction was to spontaneously occur according to Le Chatelier principle, leading to an obvious reduction in the over-potential. This finding was crucial for an innovative strategy that effectively minimizes polarization for HELAB application using an aqueous solution. The equilibrium voltage (average of charge and discharge voltages, approximately 2.9-3 V) after employing the saturated $\mathrm{LiOH}$ in $11.6 \mathrm{M} \mathrm{LiCl}$ was lower than that when employing the former (approximately 3.4 V). The decline in the equilibrium voltage may be explained by the fact that the cathodic reaction tends to follow the two-electron mechanism instead of four-electron mechanism when using the saturated $\mathrm{LiOH}$ in 11.6 M LiCl [54]. Particularly, the discharge equilibrium voltage when employing the saturated $\mathrm{LiOH}$ in $11.6 \mathrm{M} \mathrm{LiCl}$ is lower than that with the dilute counterpart, suggesting the two-electron mechanism as a possible cell mechanism. Adam et al. [54] suggested that this may be attributable to low $\mathrm{O}_{2}$ solubility in concentrated solution, promoting peroxide formation. The concentrated solution may impede the cathode's catalytic activity. Interestingly, even though the cell reaction may be dependent on two-electron mechanism, tremendous enhancement can be seen in Figure 7. Therefore, the advantages of saturated $\mathrm{LiOH}$ in the $11.6 \mathrm{M} \mathrm{LiCl}$ should outweigh the disadvantages. Regarding the long-term stability, a continuous flow of electrolyte should be used to refresh the possible formation of peroxide and other deposits. Overall, saturated $\mathrm{LiOH}$ in $11.6 \mathrm{M} \mathrm{LiCl}$ served as an effective strategy to improve the efficiency of the assembled HELABs. 


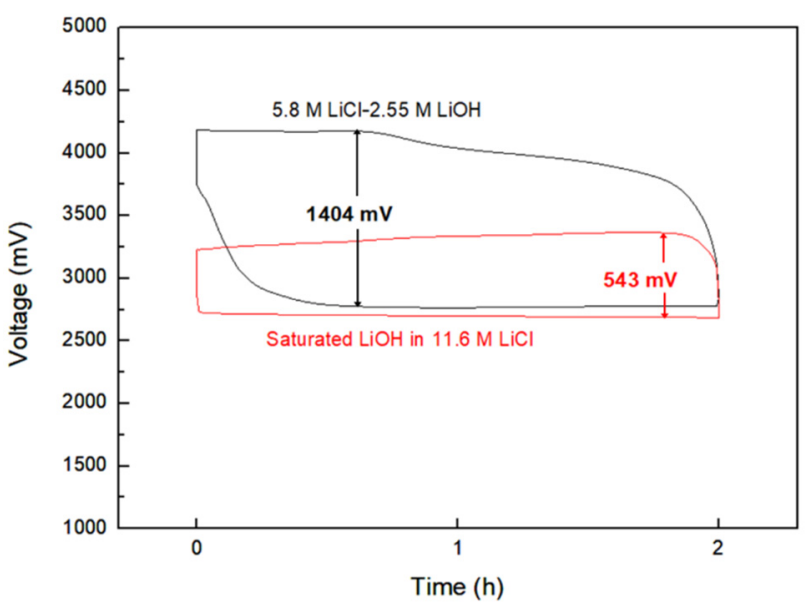

Figure 7. The voltage profile for HELABs employing 5.8 M LiCl-2.55 M LiOH and saturated $\mathrm{LiOH}$ in 11.6 $\mathrm{M} \mathrm{LiCl}$ as the aqueous electrolytes. The cathode catalyst is $\mathrm{Co}_{3} \mathrm{O}_{4} / \mathrm{GR}(\mathrm{CC})$.

According to the experimental outcomes, the saturated $\mathrm{LiOH}$ in $11.6 \mathrm{M} \mathrm{LiCl}$ greatly enhanced the charging reaction in our HELABs. In alkaline solution, solvated $\mathrm{LiOH}$ first formed in the discharging reaction forward reaction in Equation (1) and was further dissociated into solvated $\mathrm{Li}^{+}$and $\mathrm{OH}^{-}$ions (forward reaction in Equation (2)) in the aqueous environment:

$$
\begin{gathered}
4 \mathrm{Li}_{(\mathrm{s})}+\mathrm{O}_{2(\mathrm{~g})}+2 \mathrm{H}_{2} \mathrm{O}_{(\mathrm{l})} \leftrightarrows 4 \mathrm{LiOH}_{(\mathrm{aq})} \\
\mathrm{LiOH}_{(\mathrm{aq})} \leftrightarrows \mathrm{Li}^{+}{ }_{(\mathrm{aq})}+\mathrm{OH}^{-}{ }_{(\mathrm{aq})}
\end{gathered}
$$

For the charging process, the ionic association of solvated $\mathrm{Li}^{+}$and $\mathrm{OH}^{-}$ions (i.e., the reverse reaction in Equation (2)) should be, in general, prior to the charging reaction (the reverse reaction in Equation (1)). The entire charging process would include the two steps mentioned above when the HELAB is operated in an unsaturated aqueous electrolyte solution (Figure 8a). However, by effectively suppressing the dissociation of solvated $\mathrm{LiOH}$, the presented saturated $\mathrm{LiOH}$ in $11.6 \mathrm{M} \mathrm{LiCl}$ offered a facile reaction route to expedite the charging reaction through a single-step route (Figure $8 \mathrm{~b}$ ). As a result, the superior enhancement may be explained in terms of a highly reversible reaction for Equation (1). The unnecessary reaction Equation (2) could be greatly removed as saturated $\mathrm{LiOH}$ in $11.6 \mathrm{M}$ $\mathrm{LiCl}$ was employed, leading to the suppression of dissociation. The reaction mechanism is interesting and plays a positive role in aqueous Li/air batteries [56,57]. Furthermore, the employed saturated $\mathrm{LiOH}$ in $11.6 \mathrm{M} \mathrm{LiCl}$ also led to a different cell reaction pathway, because the equilibrium voltage of the HELAB is different from that with the unsaturated aqueous solution, being an average of $524 \mathrm{mV}$ lower (Figure 7, from the difference in average voltage values of the first discharge and charge cycles). This result could be attributed to the changes in the OER mechanisms. Adam et al. [54] proposed a two-electron ORR mechanism at the discharge stage. For the OER reaction at the charge cycle, either a two-electron mechanism (with a standard voltage of $2.96 \mathrm{~V}$ ) or a four-electron mechanism (with a voltage of $3.44 \mathrm{~V}$ ) is possible. By suppressing the dissociation of the solvated $\mathrm{LiOH}$, the HELAB operated under saturated $\mathrm{LiOH}$ in $11.6 \mathrm{M} \mathrm{LiCl}$ is expected to follow the two-electron OER mechanism. This pathway would significantly reduce the OER equilibrium potential, resulting in a lowered charge voltage profile, as shown in Figure 7. In the past, Adam et al. [54] used 5.0 M LiOH and $10 \mathrm{M} \mathrm{LiCl}$ separately for different aqueous electrolytes, pointing out that a concentrated solution may impede catalytic performance. Contrarily to their results, hybrid electrolyte $\mathrm{LiCl}-\mathrm{LiOH}$ solutions are employed in this work, while saturated $\mathrm{LiOH}$ in $11.6 \mathrm{M} \mathrm{LiCl}$ displays a superior round-trip efficiency of $83 \%$ using a synthesized $\mathrm{Co}_{3} \mathrm{O}_{4} / \mathrm{GR}$ composite under ambient air. The enhancement is likely ascribed to the suppression of $\mathrm{LiOH}$ dissociation, significantly facilitating the charge reaction. More importantly, 
$\mathrm{Co}_{3} \mathrm{O}_{4} / \mathrm{GR}$ fit in very well in this system. This finding is interesting because it opens up a new strategy for aqueous Li/air batteries utilizing alkaline-stable catalysts in an alkaline environment.

(a) With unsaturated aqueous solution:

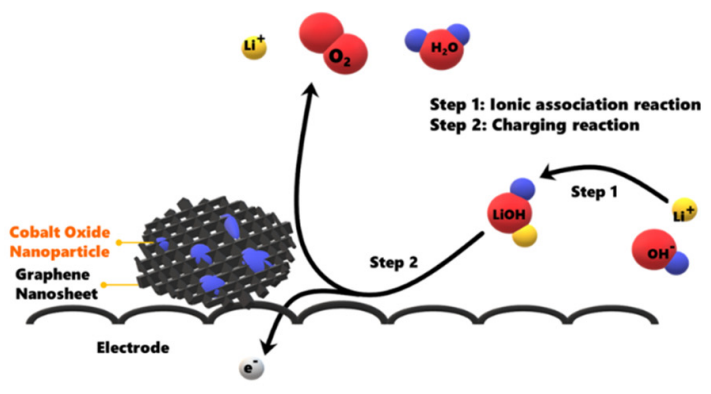

(b) With saturated aqueous solution:

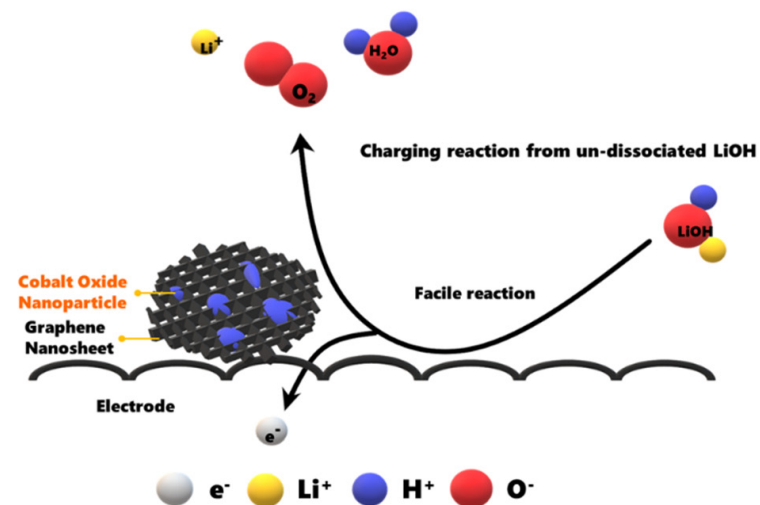

Figure 8. The electrochemical reaction route for the charge process when employing (a) an unsaturated aqueous solution or (b) saturated $\mathrm{LiOH}$ in $11.6 \mathrm{M} \mathrm{LiCl}$ in the air cathode.

\section{Conclusions}

We successfully prepared an efficient $\mathrm{Co}_{3} \mathrm{O}_{4} / \mathrm{GR}$ cathode catalyst for HELABs to operate in ambient air with a high humidity of $>70 \%$. This octahedral cobalt oxide $\left(\mathrm{Co}_{3} \mathrm{O}_{4}\right)$ was synthesized onto graphene (GR) nanosheets via a two-step preparation method. The precursor cobalt solution reacted with GR during the initial hydrolysis step to form intermediates. A subsequent hydrothermal reaction promoted $\mathrm{Co}_{3} \mathrm{O}_{4}$ crystallinity with a crystalline size of $73 \mathrm{~nm}$, resulting in octahedral particles of 100-300 $\mathrm{nm}$ in size. The as-prepared $\mathrm{Co}_{3} \mathrm{O}_{4} / \mathrm{GR}$ composite demonstrated great capability for ORR/OER in the LSV tests and cycling performance, largely improving the bare air cathode OER ability by 17.36 times. This $\mathrm{Co}_{3} \mathrm{O}_{4} / \mathrm{GR}$ catalyst resulted in a HELAB over-potential reduction of $34 \%$ and a longer lifetime than that without catalyst. The HELAB can operate for $80 \mathrm{~h}$ with a negligible increase in the over-potential and achieve a round-trip efficiency of $83 \%$. More importantly, the saturated $\mathrm{LiOH}$ in 11.6 $\mathrm{M} \mathrm{LiCl}$ was employed as an aqueous electrolyte, and the over-potential had a drastic reduction of $61 \%$. It is proposed that the suppressed dissociation of $\mathrm{LiOH}$ expedites the charging reaction from un-dissociated $\mathrm{LiOH}$. Therefore, the $\mathrm{Co}_{3} \mathrm{O}_{4} / \mathrm{GR}$ composite is a promising bi-functional catalyst, and the aforementioned concepts are crucial to the development of high-performance HELABs in the future.

Supplementary Materials: The following is available online at http://www.mdpi.com/2079-4991/10/6/1122/s1, Figure S1: XRD patterns of raw GR sheets and hydrothermal treated GR.

Author Contributions: S.-H.P., H.-C.L. and S.J.L. conceived and designed this work. S.-H.P. performed the experiments. H.-C.L. and S.J.L. provided funding to this research. All of the authors participated in the data analyses and discussions, as well as revised the entire manuscript. All authors have read and agreed to the published version of the manuscript.

Funding: This work was funded by the Ministry of Science and Technology (MOST-108-2221-E-182-021-MY3 and MOST-103-2221-E-182-056-MY3).

Acknowledgments: The authors acknowledge the technical support from Tse-Hsi Chen and Chih-Hsun Lee for LICM preparation.

Conflicts of Interest: The authors declare no conflict of interest.

\section{References}

1. Kumar, B.; Kumar, J.; Leese, R.; Fellner, J.P.; Rodrigues, S.J.; Abraham, K.M. A solid-state, rechargeable, long cycle life lithium-air battery. J. Electrochem. Soc. 2010, 157, A50. [CrossRef]

2. Imanishi, N.; Yamamoto, O. Perspectives and challenges of rechargeable lithium-air batteries. Mater. Today Adv. 2019, 4, 100031. [CrossRef] 
3. Guo, Z.; Li, C.; Liu, J.; Wang, Y.; Xia, Y. A long-life lithium-air battery in ambient air with a polymer electrolyte containing a redox mediator. Angew. Chem. Int. Ed. 2017, 56, 7505-7509. [CrossRef] [PubMed]

4. Girishkumar, G.; McCloskey, B.; Luntz, A.C.; Swanson, S.; Wilcke, W. Lithium-air battery: Promise and challenges. J. Phys. Chem. Lett. 2010, 1, 2193-2203. [CrossRef]

5. Christensen, A.; Albertus, P.; Sanchez-Carrera, R.S.; Lohmann, T.; Kozinsky, B.; Liedtke, R.; Ahmed, J.; Kojic, A. A critical review of Li/air batteries. J. Electrochem. Soc. 2012, 159, R1-R30. [CrossRef]

6. Aurbach, D.; McCloskey, B.D.; Nazar, L.F.; Bruce, P.G. Advances in understanding mechanisms underpinning lithium-air batteries. Nat. Energy 2016, 1, 16128. [CrossRef]

7. Grande, L.; Paillard, E.; Hassoun, J.; Park, J.-B.; Lee, Y.-J.; Sun, Y.-K.; Passerini, S.; Scrosati, B. The lithium/air battery: Still an emerging system or a practical reality? Adv. Mater. 2015, 27, 784-800. [CrossRef]

8. Wang, L.; Pan, J.; Zhang, Y.; Cheng, X.; Liu, L.; Peng, H. A Li-air battery with ultralong cycle life in ambient air. Adv. Mater. 2018, 30, 1704378. [CrossRef]

9. Zhao, Z.; Huang, J.; Peng, Z. Achilles Heel of lithium-air batteries: Lithium carbonate. Angew. Chem. Int. Ed. 2018, 57, 3874-3886. [CrossRef] [PubMed]

10. Asadi, M.; Sayahpour, B.; Abbasi, P.; Ngo, A.T.; Karis, K.; Jokisaari, J.R.; Liu, C.; Narayanan, B.; Gerard, M.; Yasaei, P.; et al. A lithium-oxygen battery with a long cycle life in an air-like atmosphere. Nature 2018, 555, 502-506. [CrossRef]

11. Huang, Z.; Ren, J.; Zhang, W.; Xie, M.; Li, Y.; Sun, D.; Shen, Y.; Huang, Y. Protecting the Li-metal anode in a Li-O 2 battery by using boric acid as an SEI-forming additive. Adv. Mater. 2018, 30, 1803270. [CrossRef] [PubMed]

12. Tang, M.; Chang, J.C.; Kumar, S.R.; Lue, S.J. Glyme-based electrolyte formulation analysis in aprotic lithium-oxygen battery and its cyclic stability. Energy 2019, 187, 115926. [CrossRef]

13. Lai, J.; Xing, Y.; Chen, N.; Li, L.; Wu, F.; Chen, R. Electrolytes for rechargeable lithium-air batteries. Angew. Chem. Int. Ed. 2019, 59, 2974-2997. [CrossRef] [PubMed]

14. Wang, Y.G.; Zhou, H.S. A lithium-air battery with a potential to continuously reduce $\mathrm{O}_{2}$ from air for delivering energy. J. Power Sources 2010, 195, 358-361. [CrossRef]

15. Wang, Y.G.; Zhou, H.S. A lithium-air fuel cell using copper to catalyze oxygen-reduction based on copper-corrosion mechanism. Chem. Commun. 2010, 46, 6305-6307. [CrossRef]

16. Lu, Y.; Goodenough, J.B.; Kim, Y. Aqueous cathode for next-generation alkali-ion batteries. J. Am. Chem. Soc. 2011, 133, 5756-5759. [CrossRef]

17. He, H.; Niu, W.; Asl, N.M.; Salim, J.; Chen, R.R.; Kim, Y. Effects of aqueous electrolytes on the voltage behaviors of rechargeable Li-air batteries. Electrochim. Acta 2012, 67, 87-94. [CrossRef]

18. Wang, L.; Zhao, X.; Lu, Y.; Xu, M.; Zhang, D.; Ruoff, R.S.; Stevenson, K.J.; Goodenough, J.B. CoMn $2 \mathrm{O}_{4}$ spinel nanoparticles grown on graphene as bifunctional catalyst for lithium-air batteries. J. Electrochem. Soc. 2011, 158, A1379-A1382. [CrossRef]

19. Zhu, X.B.; Zhao, T.S.; Wei, Z.H.; Tan, P.; An, L. A high-rate and long cycle life solid-state lithium-air battery. Energy Environ. Sci. 2015, 8, 3745-3754. [CrossRef]

20. Zhang, W.; Nie, J.; Li, F.; Wang, Z.L.; Sun, C. A durable and safe solid-state lithium battery with a hybrid electrolyte membrane. Nano Energy 2018, 45, 413-419. [CrossRef]

21. Imanishi, N.; Hasegawa, S.; Zhang, T.; Hirano, A.; Takeda, Y.; Yamamoto, O. Lithium anode for lithium-air secondary batteries. J. Power Sources 2008, 185, 1392-1397. [CrossRef]

22. Pan, J.; Tian, X.L.; Zaman, S.; Dong, Z.; Liu, H.; Park, H.S.; Xia, B.Y. Recent progress on transition metal oxides as bifunctional catalysts for lithium-air and zinc-air batteries. Batter. Supercaps 2019, 2, 336-347. [CrossRef]

23. Cao, X.; Yang, R. Advances in electrocatalysts for the cathode of Li-air batteries. Chin. Sci. Bull. 2019, 64, 3340-3349.

24. Abraham, K.M.; Jiang, Z. A polymer electrolyte-based rechargeable lithium/oxygen battery. J. Electrochem. Soc. 1996, 143, 1-5. [CrossRef]

25. Lu, Y.C.; Kwabi, D.G.; Yao, K.P.C.; Hardling, J.R.; Zhou, J.G.; Zuin, L.; Shao-Horn, Y. The discharge rate capability of rechargeable $\mathrm{Li}-\mathrm{O}_{2}$ batteries. Energy Environ. Sci. 2011, 4, 2999-3007. [CrossRef]

26. Beattie, S.D.; Manolescu, D.M.; Blair, S.L. High-capacity lithium-air cathodes. J. Electrochem. Soc. 2009, 156, A44-A47. [CrossRef]

27. Lu, Y.C.; Gasteiger, H.A.; Shao-Horn, Y. Catalytic activity trends of oxygen reduction reaction for nonaqueous Li-air batteries. J. Am. Chem. Soc. 2011, 133, 19048-19051. [CrossRef] 
28. Roena, L.M.; Paikb, C.H.; Jarvic, T.D. Electrocatalytic corrosion of carbon support in PEMFC cathodes. Electrochem. Solid-State Lett. 2004, 7, A19-A22. [CrossRef]

29. Kangasniemia, K.H.; Conditb, D.A.; Jarvic, T.D. Characterization of Vulcan electrochemically oxidized under simulated PEM fuel cell conditions. J. Electrochem. Soc. 2004, 151, E125-E132. [CrossRef]

30. Antolini, E. Formation, microstructural characteristics and stability of carbon supported platinum catalysts for low temperature fuel cells. J. Mater. Sci. 2003, 38, 2995-3005. [CrossRef]

31. Wang, X.; Li, W.; Chen, Z.; Waje, M.; Yan, Y. Durability investigation of carbon nanotube as catalyst support for proton exchange membrane fuel cell. J. Power Sources 2006, 154, 154-159. [CrossRef]

32. Shao, Y.; Yin, G.; Gao, Y.; Shi, P. Durability study of Pt/C and Pt/CNTs catalysts under simulated PEM fuel cell conditions. J. Electrochem. Soc. 2006, 153, A1093-A1097. [CrossRef]

33. Liang, Y.; Li, Y.; Wang, H.; Zhou, J.; Wang, J.; Regier, T.; Dai, $\mathrm{H} . \mathrm{Co}_{3} \mathrm{O}_{4}$ nanocrystals on graphene as a synergistic catalyst for oxygen reduction reaction. Nat. Mater. 2011, 10, 780-786. [CrossRef] [PubMed]

34. Sun, C.; Li, F.; Ma, C.; Wang, Y.; Ren, Y.; Yang, W.; Ma, Z.; Li, J.; Chen, Y.; Kim, Y.; et al. Graphene-Co ${ }_{3} \mathrm{O}_{4}$ nanocomposite as an efficient bifunctional catalyst for lithium-air batteries. J. Mater. Chem. A 2014, 2, 7188. [CrossRef]

35. Lefevre, M.; Proietti, E.; Jaouen, F.; Dodelet, J.-P. Iron-based catalysts with improved oxygen reduction activity in polymer electrolyte fuel cells. Science 2009, 324, 71-74. [CrossRef]

36. Bezerra, C.W.B.; Zhang, L.; Lee, K.; Liu, H.; Marques, A.L.B.; Marques, E.P.; Wang, H.; Zhang, J. A review of $\mathrm{Fe}-\mathrm{N} / \mathrm{C}$ and $\mathrm{Co}-\mathrm{N} / \mathrm{C}$ catalysts for the oxygen reduction reaction. Electrochim. Acta 2008, 53, 4937-4951. [CrossRef]

37. Gong, K.; Du, F.; Xia, Z.; Durstock, M.; Dai, L. Nitrogen-doped carbon nanotube arrays with high electrocatalytic activity for oxygen reduction. Science 2009, 323, 760-764. [CrossRef]

38. Liu, R.; Wu, D.; Feng, X.; Muellen, K. Nitrogen-doped ordered mesoporous graphitic arrays with high electrocatalytic activity for oxygen reduction. Angew. Chem. Int. Ed. 2010, 49, 2565-2569. [CrossRef]

39. Hang, Y.; Zhang, C.; Luo, X.; Xie, Y.; Xin, S.; Li, Y.; Zhang, D.; Goodenough, J.B. $\alpha-\mathrm{MnO}_{2}$ nanorods supported on porous graphitic carbon nitride as efficient electrocatalysts for lithium-air batteries. J. Power Sources 2018, 392, 15-22. [CrossRef]

40. Surya, K.; Michael, M.S.; Prabaharan, S.R.S. A review on advancement in non-noble metal based oxides as bifunctional catalysts for rechargeable non-aqueous Li/air battery. Solid State Ion. 2018, 317, 89-96. [CrossRef]

41. Lim, H.; Gwon, H.; Kim, H.; Kim, S.; Yoon, T.; Choi, J.W.; Oh, S.M.; Kang, K. Mechanism of $\mathrm{Co}_{3} \mathrm{O}_{4} /$ grapheme catalytic activity in $\mathrm{Li}-\mathrm{O}_{2}$ batteries using carbonate based electrolyte. Electrochim. Acta 2013, 90, 63-70. [CrossRef]

42. Peng, S.H.; Chen, T.H.; Li, C.H.; Lu, H.C.; Lue, S.J. Optimal cobalt oxide $\left(\mathrm{Co}_{3} \mathrm{O}_{4}\right)$ :graphene (GR) ratio in $\mathrm{Co}_{3} \mathrm{O}_{4} / \mathrm{GR}$ as air cathode catalyst for air-breathing hybrid electrolyte lithium-air battery. J. Power Sources 2020, in press.

43. Ehrhardt, C.; Gjikaj, M.; Brockner, W. Thermal decomposition of cobalt nitrato compounds: Preparation of anhydrous cobalt(II)nitrate and its characterisation by Infrared and Raman spectra. Thermochim. Acta 2005, 432, 36-40. [CrossRef]

44. Fan, Y.; Wu, Y.; Fang, P.; Sha, H.; Cha, L.; Ming, Z. $\mathrm{Co}_{2} \mathrm{O}_{3}-\mathrm{NH}_{2}-\mathrm{MCM}-41$ decorated graphite as an effective electrode:synthesis, characterization and its application for electro-catalytic oxidation of acid red 1. Electroanalysis 2017, 29, 794-805. [CrossRef]

45. Zhang, S.; Wang, H.; Liu, J.; Bao, C. Measuring the specific surface area of monolayer graphene oxide in water. Mater. Lett. 2020, 261, 127098. [CrossRef]

46. Esmaeili, A.; Entezari, M.H. Facile and fast synthesis of graphene oxide nanosheets via bath ultrasonic irradiation. J. Colloid Interface Sci. 2014, 432, 19-25. [CrossRef]

47. Wang, H.; Hu, Y.H. Effect of oxygen content on structures of graphite oxides. Ind. Eng. Chem. Res. 2011, 50, 6132-6137.

48. Montes-Navajas, P.; Asenjo, N.G.; Santamaría, R.; Menéndez, R.; Corma, A.; García, H. Surface area measurement of graphene oxide in aqueous solutions. Langmuir 2013, 29, 13443-13448. [CrossRef]

49. Rashad, M.; Rüsing, M.; Berth, G.; Lischka, K.; Pawlis, A. $\mathrm{CuO}$ and $\mathrm{Co}_{3} \mathrm{O}_{4}$ nanoparticles: Synthesis, characterizations, and raman spectroscopy. J. Nanomater. 2013, 2013, 714853. [CrossRef]

50. Samal, R.; Dash, B.; Sarangi, C.K.; Sanjay, K.; Subbaiah, T.; Senanayake, G.; Minakshi, M. Influence of Synthesis Temperature on the Growthand Surface Morphology of $\mathrm{Co}_{3} \mathrm{O}_{4}$ Nanocubes for Supercapacitor Applications. Nanomaterials 2017, 7, 356. [CrossRef] 
51. Yang, X.; Lu, C.; Qin, J.; Zhang, R.; Tang, H.; Song, H. A facile one-step hydrothermal method to produce graphene- $\mathrm{MoO}_{3}$ nanorod bundle composites. Mater. Lett. 2011, 65, 2341-2344. [CrossRef]

52. Shia, P.; Sua, R.; Zhua, S.; Zhua, M.; Li, D.; Xua, S. Supported cobalt oxide on graphene oxide: Highly efficient catalysts for the removal of Orange II from water. J. Hazard. Mater. 2012, 229-230, 331-339. [CrossRef] [PubMed]

53. Cheng, P.; Yang, Z.; Wanga, H.; Cheng, W.; Chen, M.; Shangguan, W.; Ding, G. TiO 2 -graphene nanocomposites for photocatalytic hydrogen production from splitting water. Int. J. Hydrogen Energy 2012, 37, 2224-2230. [CrossRef]

54. Safanama, D.; Adams, S. High efficiency aqueous and hybrid lithium-air batteries enabled by $\mathrm{Li}_{1.5} \mathrm{Al}_{0.5} \mathrm{Ge}_{1.5}\left(\mathrm{PO}_{4}\right)_{3}$ ceramic anode-protecting membranes. J. Power Sources 2017, 340, 294-301. [CrossRef]

55. Shimonishi, Y.; Zhang, T.; Imanishi, N.; Im, D.; Joon Lee, D.; Hirano, A.; Takeda, Y.; Yamamoto, O.; Sammes, N. A study on lithium/air secondary batteries-Stability of the NASICON-type lithium ion conducting solid electrolyte in alkaline aqueous solutions. J. Power Sources 2011, 196, 5128-5132. [CrossRef]

56. Minakshi, M.; Sharma, N.; Ralph, D.; Appadoo, D.; Nallathambyd, K. Synthesis and Characterization of $\mathrm{Li}\left(\mathrm{Co}_{0.5} \mathrm{Ni}_{0.5}\right) \mathrm{PO}_{4}$ Cathode for Li-Ion Aqueous Battery Applications. Electrochem Solid-State Lett. 2011, 14, A86-A89. [CrossRef]

57. Minakshi, M.; Singh, P.; Issa, T.B.; Thurgate, S.; De Marco, R. Lithium insertion into manganese dioxide electrode in $\mathrm{MnO}_{2} / \mathrm{Zn}$ aqueous battery Part III. Electrochemical behavior of $-\mathrm{MnO}_{2}$ in aqueous lithium hydroxide electrolyte. J. Power Sources 2006, 153, 165. [CrossRef]

(C) 2020 by the authors. Licensee MDPI, Basel, Switzerland. This article is an open access article distributed under the terms and conditions of the Creative Commons Attribution (CC BY) license (http://creativecommons.org/licenses/by/4.0/). 